\title{
IDENTIFIKASI DAN HABITAT GURITA (CEPHALOPODA) DARI PERAIRAN SALIBABU, KABUPATEN KEPULAUAN TALAUD
}

\author{
(Identification and Habitat (Cephalopoda) in the Coastal Area of Salibabu, District of \\ Talaud Archipelago)
}

\author{
Andika R. Balansada, Medy Ompi, Frans Lumuindong \\ Program Studi IImu Kelautan, Fakultas Perikanan dan Ilmu Kelautan, Universitas \\ Sam Ratulangi, Manado. \\ e-mail : abalansada@gmail.com
}

\begin{abstract}
The octopus in Manado language is called Boboca, while the local Talaud community is called Urrita. Octopus is used as food and bait. Information on octopus biology needs to be known as basic information in the management of octopus resources. This study aims to identify and provide information on octopus habitat in the waters of Salibabu. Collecting specimens using arrows (jubi). The morphology of the example octopus is identified as Octopus cyanea Gray, 1849. In the arms of the octopus there are white-colored spots. On the left and right side of the crown of the arm are two false eyes (ocellus). On the face of the ventral arm is a dark pole pattern above the pale or creamy base color. Characteristics of female morphomes generally have a larger size compared to males. Specimen habitats are found outside the nest at night and in the nest during the day time.
\end{abstract}

Keywoeds: Octopus, Biology, Identify, Morphology, Morphometric, Habitat

Gurita dalam bahasa Manado disebut Boboca, sedangkan oleh masyarakat lokal Talaud disebut Urrita. Gurita dimanfaatkan sebagai bahan makanan dan umpan. Informasi biologi gurita perlu diketahui sebagai informasi dasar dalam pengelolaan sumberdaya gurita. Penelitian ini bertujuan untuk identifikasi dan menyediakan informasi habitat gurita yang ada di perairan Salibabu. Pengambilan spesimen menggunakan panah (jubi). Morfologi gurita contoh diidentifikasi sebagai Octopus cyanea Gray, 1849. Pada bagian lengan gurita terdapat bintikbintik berwarnah putih. Pada samping kiri dan kanan mahkota lengan terdapat dua mata palsu (ocellus). Pada muka lengan ventral terdapat pola tiang yang gelap di atas warna dasar pucat atau krem. Karakteristik Morfomtrik betina umumnya memiliki ukuran lebih besar di bandingkan jantan. Habitat spesimen ditemukan di luar sarang pada malam hari dan di dalam sarang pada siang hari.

Kata kunci : Gurita, Biologi, Identifikasi, Morfologi, Morfometrik, Habitat 


\section{PENDAHULUAN}

Indonesia memiliki luas laut 5,8 juta $\mathrm{km}^{2}$ dengan garis pantai sepanjang $95,181 \mathrm{~km}$ serta memiliki potensi sumberdaya perikanan laut yang cukup besar baik dari segi kuantitas maupun diversitas (Rompas, et al. 2007). Daerah pantai atau daerah pasang surut, mempunyai potensi cukup besar dalam penyediaan bahan makanan bagi kehidupan manusia. Salah satu sumberdaya hayati laut yang belum banyak diinformasikan adalah jenisjenis gurita (Budiyanto dan Sugiarto, 1997).

Gurita memiliki peran ekologis penting baik sebagai predator maupun mangsa dan tergolong komoditas perikanan ekonomis penting karena mengandung gizi yang cukup tinggi dan menduduki urutan ke tiga di dalam dunia perikanan setelah ikan dan udang (Toha, et al. 2015).

Informasi mengenai biologi gurita perlu diketahui sebagai informasi dasar dalam pengelolaan sumberdaya gurita. Salah satu informasi biologi yang diperlukan untuk pengelolaan sumberdaya yang efektif yaitu kepastian spesies (Begg et al. 1999). Masalah kurangnya informasi mengenai identifikasi jenis-jenis gurita dan habitat gurita yang ada di perairan Salibabu, kecamatan Salibau, Kebupaten Kepulauan Talaud, maka perlu di lakukan penelitian mengenai identifikasi jenis-jenis gurita dan menyediakan informasi habitat gurita yang ada di perairan Salibabu, Kabupaten Kepulauan Talaud.

\section{METODE PENELITIAN}

\section{Tempat dan Waktu Penelitian}

Penelitian ini dilaksanakan di pantai Tiwinga ( $\left.3^{0} 52^{\prime} 33^{\prime \prime} \mathrm{N} 126^{\circ} 39^{\prime} 45^{\prime \prime} \mathrm{E}\right)$, Waikka, Lakendurri, Attoaha, Wambana, Tainatta, panooranna, Pinaanga, Raddapa, Awuna, Matandika, Sanggelokka, Patunga, Tarawatta ( $\left.3^{0} 50^{\prime} 30^{\prime \prime} \mathrm{N} 126^{\circ} 40^{\prime} 29^{\prime \prime} \mathrm{E}\right)$ di sebelah Barat dan Wuuran ( $3^{0} 52^{\prime} 54^{\prime \prime} N 126^{\circ} 42$ '26E), Sikkata, Waasana, Anneng Banua, Lawasana, Lahu, Nunu Umpe, Warre, Watung Asuanga ( $\left.3^{0} 50^{\prime} 52^{\prime \prime} \mathrm{N} 126^{\circ} 41^{\prime} 42^{\prime \prime} \mathrm{E}\right)$ disebelah timur Desa Salibabu, Salibabu Induk/Raya dan Dalum Kecamatan Salibabu, Kabupaten Kepulauan Talaud. Penelitian dilakukan pada bulan juni $2018 \pm 3$ minggu.

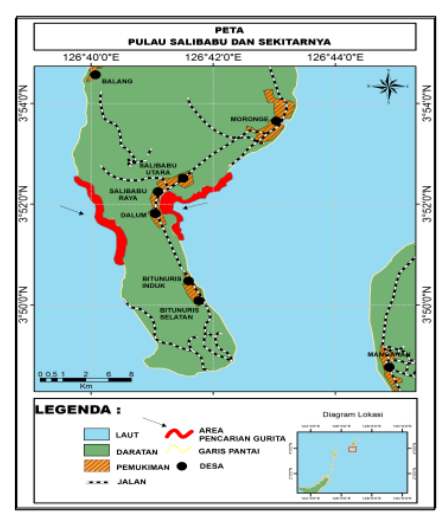

Gambar 1. Peta lokasi penelitian

\section{Metode Pengambilan Data}

\section{Pengambilan spesimen}

Penelitian ini menggunakan metode Survei jelajah yaitu menjelajah sepanjang pantai Timur dan Barat Desa Salibabu, Salibabu Induk/Raya dan Dalum Kecamatan Salibabu, Kabupaten Kepulauan Talaud di lakukan pada siang maupun malam hari dengan melakukan snorkeling dan berjalan pada saat surut. Untuk menangkap gurita di gunakan alat tangkap panah (jubi).

\section{Pengumpulan data morfologi}

Identifikasi morfologi dilakukan dengan memperhatikan ciri-ciri eksternal yang meliputi bentuk mantel, lengan, warna, hectocotylus dan paruh serta membandingkan karakteristik morfologi spesimen dengan spesies yang telah diketahui deskripsi morfologinya. Morfologi gurita dideskripsikan mengacu pada Roper 
dan Voss (1983) sedengkan Informasi mengenai karakteristik morfologi pada spesies pembanding mengacu pada FAO Species Catalogue for Fishery Purpose No 4, Vol 3, Cephalopods of The World, An Annotated and llustrated Catalogue of Cephalood Species Known To Date, Octopods and Vampire Squids (Jereb, et al. 2016) dan CSIRO Publishing, Invertebrate Taxonomy, An International Jurnal of Biosystematics, The Shallow-water Octopuses (Ceohalopoda: Octopodida) of The Philippines (Norman and Sweeney, 1997).

Tabel 1. Deskripsi pengamatan morfologi gurita

\begin{tabular}{|c|c|c|}
\hline NO & $\begin{array}{l}\text { Karakter } \\
\text { Morfologi }\end{array}$ & Deskripsi Kualitatif \\
\hline 1. & Mantel & $\begin{array}{l}\text { Bentuk, Ketebalan, } \\
\text { Bukaan Mantel }\end{array}$ \\
\hline 2. & Kepala & $\begin{array}{l}\text { Bentuk kepala dan } \\
\text { bentuk mata }\end{array}$ \\
\hline 3. & Funnel & $\begin{array}{l}\text { Bentuk funel, } \\
\text { bukaan funnel, } \\
\text { organ funnel }\end{array}$ \\
\hline 4. & Lengan & $\begin{array}{l}\text { Bentuk lengan, } \\
\text { jumlah } \\
\text { sucker }\end{array}$ \\
\hline 5. & $\begin{array}{l}\text { Suckers/pen } \\
\text { ghisap }\end{array}$ & $\begin{array}{l}\text { keberadaan } \\
\text { sucker/penghisap } \\
\text { besar }\end{array}$ \\
\hline 6. & $\begin{array}{l}\text { Selaput } \\
\text { lengan }\end{array}$ & $\begin{array}{l}\text { Tipe selaput lengan } \\
\text { (Gambar } 2 \text { ) }\end{array}$ \\
\hline 7. & Hectocotylus & $\begin{array}{l}\text { Posisi, bentuk ligula } \\
\text { dan calamus }\end{array}$ \\
\hline & Kulit & $\begin{array}{l}\text { Corak warna, } \\
\text { kromatofor, } \\
\text { Ocellus, tonjolan } \\
\text { papila }\end{array}$ \\
\hline
\end{tabular}

Sumber: Roper dan Voss, (1983)

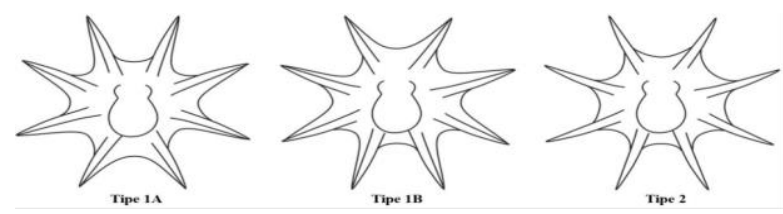

Gambar 2. Tipe selaput lengan pada gurita (Garcia, 2010)

\section{Pengumpulan data morfometrik}

\begin{tabular}{lcrr}
\multicolumn{3}{c}{ Pengumpulan data } & morfometrik \\
dilakukan & dengan & melakukan \\
pengukuran & pada & 15 & karakter \\
morfometrik & gurita. & Deskripsi
\end{tabular}
morfometrik gurita mengacu pada Huffard and Hochberg (2005).

Tabel 2. Karakter Morfometrik Pada Gurita

\begin{tabular}{|c|c|c|}
\hline Kode & Karakter & Definisi \\
\hline ML & $\begin{array}{l}\text { Panjang } \\
\text { mantel } \\
\text { (Mantle } \\
\text { length) }\end{array}$ & $\begin{array}{l}\text { Panjang dari } \\
\text { titik tengah } \\
\text { kedua mata } \\
\text { hingga ujung } \\
\text { akhir mantel. }\end{array}$ \\
\hline$A L$ & $\begin{array}{l}\text { Panjang } \\
\text { lengan (Arm } \\
\text { length) }\end{array}$ & $\begin{array}{l}\text { Panjang lengan } \\
\text { yang diukur dari } \\
\text { mulut (paruh) } \\
\text { ke ujung } \\
\text { lengan. }\end{array}$ \\
\hline ASe & $\begin{array}{l}\text { Diameter } \\
\text { penghisap } \\
\text { besar } \\
\text { (Arm sucker } \\
\text { diameter } \\
\text { enlarged) }\end{array}$ & $\begin{array}{l}\text { Diameter dari } \\
\text { penghisap } \\
\text { berukuran } \\
\text { besar. }\end{array}$ \\
\hline ASD & $\begin{array}{l}\text { Diameter } \\
\text { penghisap } \\
\text { normal } \\
\text { (Arm sucker } \\
\text { diameter } \\
\text { normal) }\end{array}$ & $\begin{array}{l}\text { Diameter dari } \\
\text { penghisap } \\
\text { berukuran } \\
\text { norma. }\end{array}$ \\
\hline ASC & $\begin{array}{l}\text { Jumlah } \\
\text { penghisap } \\
\text { (Arm sucker } \\
\text { count) }\end{array}$ & $\begin{array}{l}\text { Jumlah } \\
\text { penghisap di } \\
\text { sepanjang } \\
\text { lengan tertentu } \\
\text { yang utuh } \\
\text { (hingga ujung } \\
\text { lengan). }\end{array}$ \\
\hline CaL & $\begin{array}{l}\text { Panjang } \\
\text { calamus } \\
\text { (Calamus } \\
\text { length) }\end{array}$ & $\begin{array}{l}\text { Panjang dari } \\
\text { penghisap } \\
\text { paling ujung } \\
\text { hingga ujung } \\
\text { akhir calamus. }\end{array}$ \\
\hline EO & $\begin{array}{l}\text { Diameter } \\
\text { lubang mata } \\
\text { (Eye orifice } \\
\text { diameter) }\end{array}$ & $\begin{array}{l}\text { Diameter } \\
\text { bukaan mata. }\end{array}$ \\
\hline FUL & $\begin{array}{l}\text { Panjang } \\
\text { corong }\end{array}$ & $\begin{array}{l}\text { Panjang corong } \\
\text { dari mulut }\end{array}$ \\
\hline
\end{tabular}




\begin{tabular}{|c|c|c|}
\hline & $\begin{array}{l}\text { (Funnel } \\
\text { length) }\end{array}$ & $\begin{array}{l}\text { bukaan hingga } \\
\text { batas pangkal, } \\
\text { diukur di } \\
\text { sepanjang garis } \\
\text { tengah ventral }\end{array}$ \\
\hline HdL & $\begin{array}{l}\text { Panjang } \\
\text { kepala } \\
\text { (Head } \\
\text { length) }\end{array}$ & $\begin{array}{l}\text { Diameter } \\
\text { lengkungan } \\
\text { sepanjang } \\
\text { sumbu depan } \\
\text { hingga } \\
\text { belakang tubuh. }\end{array}$ \\
\hline HdW & $\begin{array}{l}\text { Lebar kepala } \\
\text { (Head width) }\end{array}$ & $\begin{array}{l}\text { Lebar terjauh } \\
\text { pada kepala } \\
\text { pada tingkat } \\
\text { mata. }\end{array}$ \\
\hline LL & $\begin{array}{l}\text { Panjang } \\
\text { ligula }\end{array}$ & $\begin{array}{l}\text { Panjang dari } \\
\text { penghisap } \\
\text { paling ujung } \\
\text { hingga ujung } \\
\text { dari lengan } \\
\text { hectocotylus }\end{array}$ \\
\hline MW & $\begin{array}{l}\text { Lebar mantel } \\
\text { (Mantle } \\
\text { width) }\end{array}$ & $\begin{array}{l}\text { Lebar garis } \\
\text { dorsal terjauh } \\
\text { pada mantel }\end{array}$ \\
\hline PA & $\begin{array}{l}\text { Lebar } \\
\text { bukaan } \\
\text { mantel } \\
\text { (Pallial } \\
\text { Aperture } \\
\text { Extent) }\end{array}$ & $\begin{array}{l}\text { Panjang antara } \\
\text { kedua titik } \\
\text { penempelan } \\
\text { mantel ke } \\
\text { kepala di } \\
\text { sepanjang } \\
\text { batas ventral } \\
\text { mantel }\end{array}$ \\
\hline TL & $\begin{array}{l}\text { Panjang total } \\
\text { (Total length) }\end{array}$ & $\begin{array}{l}\text { Panjang dari } \\
\text { ujung lengan } \\
\text { terpanjang } \\
\text { hingga ujung } \\
\text { akhir mantel }\end{array}$ \\
\hline WD & $\begin{array}{l}\text { Lebar } \\
\text { selaput } \\
\text { lengan (Web } \\
\text { depth) }\end{array}$ & $\begin{array}{l}\text { Ukuran sektor } \\
\text { selaput lengan } \\
\text { terdalam dari } \\
\text { mulut (paruh) } \\
\text { hingga titik } \\
\text { tengah sektor }\end{array}$ \\
\hline
\end{tabular}

Sumber: Huffard and Hochberg (2005)

\section{Habitat spesimen}

\begin{tabular}{lrr}
\multicolumn{1}{c}{ Dalam } & penelitian & ini \\
Pengumpulan data mengenai & habitat \\
spesimen & menggunakan & teknik \\
obsevasi Survey jelaja. & Teknik
\end{tabular}

observasi adalah suatu teknik pengumpulan data di mana peneliti mencatat setiap informasi sesuai dengan kenyataan yang dilihat selama penelitian berlangsung (Soleh, 2005). Langkah yang dilakukan selama pengumpilan data habitat adalah sebagai berikut:

1. Mencatat nama lokasi ditemukanya gurita

2. Mengambil foto lokasi di temukanya gurita

\section{HASIL DAN PEMBAHASAN}

Octopus yang diperoleh 22 individu terdiri dari 10 jantan dan 12 betina.

\section{Deskripsi morfologi spesimen}

Deskripsi morfologi spesimen gurita yang ditemukan di perairan salibau memiliki mantel berbentuk oval, otot tebal, bukaan mantel sangat besar dan memiliki 4 tonjolan papilia pada dorsal mantel (Gambar 8 dan Gambar 10), kepala menonjol dan berukuran sadang, terdapat struktur yang sedikit keras pada bagian dorsal kepala, mata berukuran kecil dan menonjol, mempunyai 3 ears di bagian atas mata (Gambar 9), funnel berbentuk huruf W, bukan funnel kecil, funnel berukuran besar, menempel pada bukaan palial(Gambar 10), memiliki lengan yang panjang dan mengecil pada ujungnya dengan posisi penghisap/sucker 2 baris. Pada jentan ditemukan penghisap besar (Gambar 10). Selaput lengan tipe 1A. Hectocotylus terletak pada lengan ke tiga disisi kanan tubuh pada jantan, ukuran ligula dan calamus yang sangat kecil (Gambar 5) dan kulit Memiliki tekstur berkerut pada bagian dorsal dan bertekstur halus pada bagian ventral, mempunya warna coklat, putih, putih kebiruan, coklat gelap, dan krem (Gambar 3). Memiliki sepasang Ocellus berupa bintik hitam berbentuk oval yang dikelilingi cincin berwarna 
pucat pada bagian dalam dan warna coklat kehitaman (gelap) pada bagian luar (Gambar 6), Pada permukaan lateral lengan terdapat pola berupa potongan zebra dan memiliki bintikbintik putih pada lengan (Gambar 4, dan Gambar 7).

\section{Identifikasi spesimen morfologi}

Perbandingan

morfologi

menunjukkan spesies gurita yang telah di temukankan di pantai Desa Dalum memiliki banyak ke cocokan karakteristik dengan spesies Octopus cyanea Gray, 1849. Kecocokan karakteristik antara gurita contoh dengan spesies Octopus cyanea terdapat pada karakter morfologi mantel, kepala, funnel, lengan, suckers, selaput lengan, hectocotylus, dan kulit (Gambar 3 sampai Gambar 11)
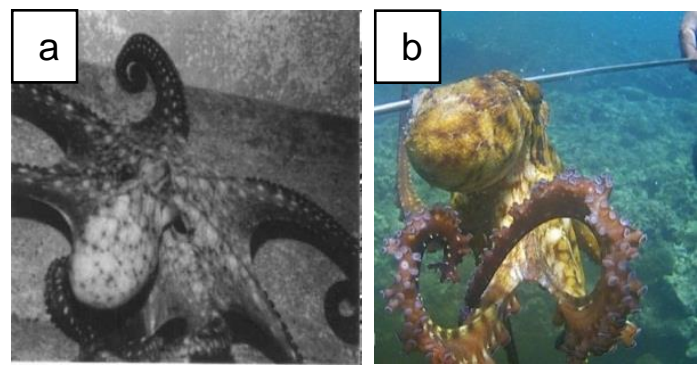

Gambar 3. a. Octopus cyanea yang suda di ketahui (Norman, 1991), b. Octopus yang di temukan dalam penelitian
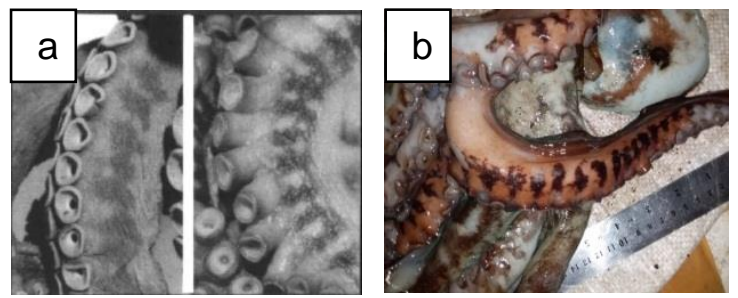

Gambar 4. a. Pola garis hitam pada lengan Octopus cyanea yang suda di ketahui (Norman, 1991), b. Pola garis hitam pada lengan

gurita yang ditemukan
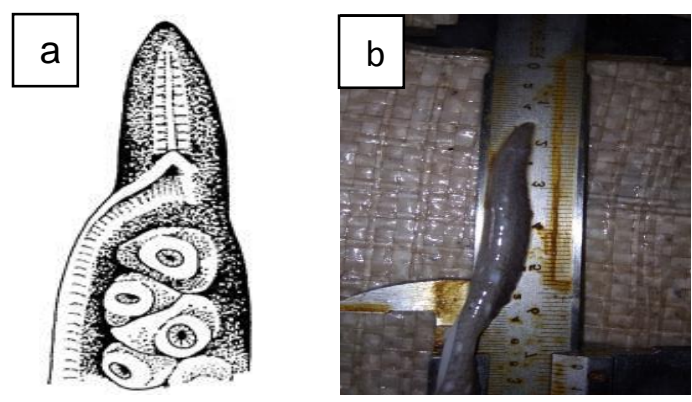

Gambar 5. a. Hectocotylus Octopus cyanea yang suda di ketahui (Norman, 1991), b Hectocotylus gurita yang ditemukan
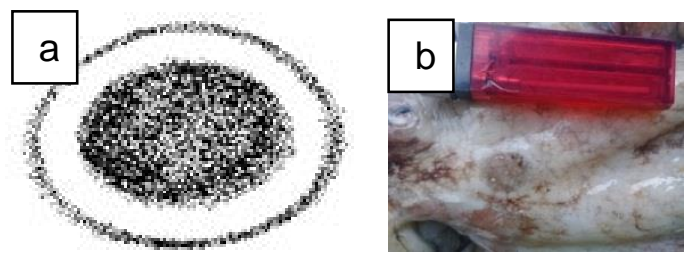

Gambar 6. a. Ocellus Octopus cyanea yang suda di ketahui (Norman, 1991), b. Ocellus Octopus yang di temukan dalam penelitian
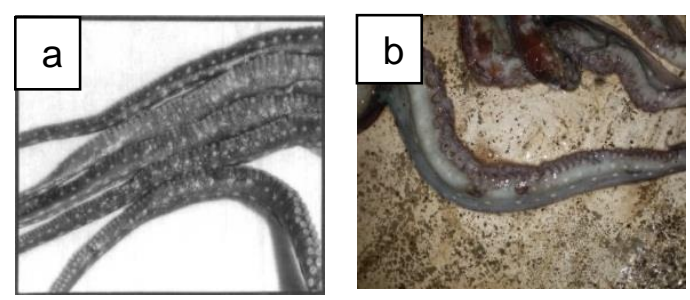

Gambar 7. a. Bintik-bintik putih pada lengan Octopus cyanea yang suda di ketahui (Norman, 1991), b. bintik-bintik putihpada lengan Octopus yang di temukan dalam penelitian 

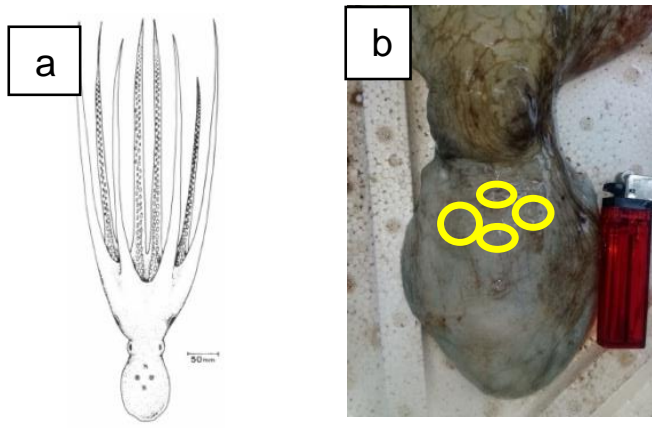

Gambar 8 . a. 4 tonjolan papilia Octopus cyanea di ketahui (Jereb, et al. 2016), b. 4 tonjolan papilia Octopus yang di temukan dalam penelitian
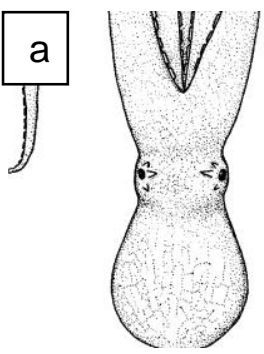

Gambar

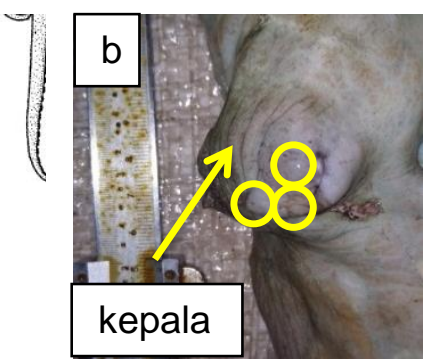

a. 4 tonjolan papilia Octopus cyanea di ketahui (Jereb, et al. 2016), b. 4 tonjolan papilia Octopus yang di temukan dalam penelitian
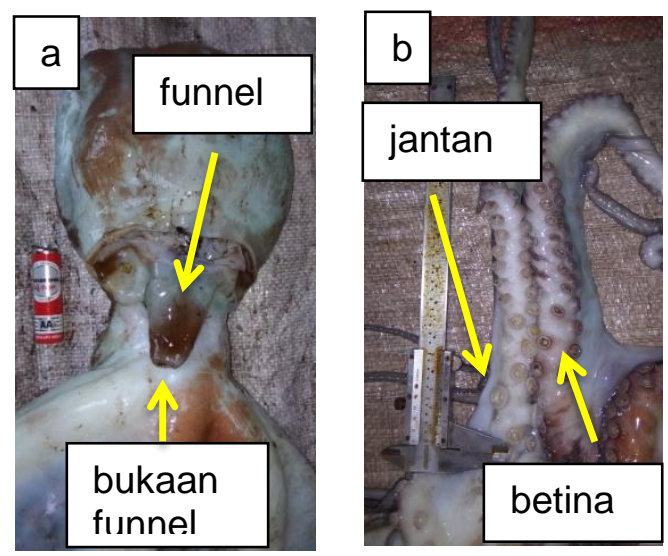

Gambar 10. a. Funel b. perbedaan penghisap jantan dan betina serta urutan 2 baris penghisap.

\section{Data karakter morfometrik}

Gurita yang di temukan umumnya betina memiliki ukuran tubeh lebi besar dibandingkan dengan jantan. Gurita paling besar ditemukan memiliki panjang total $(T L)$ mencapai $86,0 \mathrm{~cm}$ dan ukuran terkecil memiliki panjang total (TL) $67,0 \mathrm{~cm}$ untuk ukuran jantan, sedangkan pada betina ukuran terbesar memiliki panjang total (TL) $133,0 \mathrm{~cm}$ dan $91,0 \mathrm{~cm}$ untuk pananjang total (TL) ukuran terkecil. Panjang mantel (ML) mencapai $11,0 \mathrm{~cm}$ pada jantan dan $18,0 \mathrm{~cm}$ pada betina. Lebar mantel (MW) mencapai $8,5 \mathrm{~cm}$ pada jantan dan $11,5 \mathrm{~cm}$ pada betina. Lebar bukaan mantel (PA) mencapai $14,0 \mathrm{~cm}$ pada jantan dan 17,7 pada betina. Panjang kepala $(\mathrm{HdL})$ mencapai $4,4 \mathrm{~cm}$ pada jantan dan $6,0 \mathrm{~cm}$ pada betina. Lebar kepala $(\mathrm{HdW})$ mencapai $6,9 \mathrm{~cm}$ pada jantan dan $8,3 \mathrm{~cm}$ pada betina. Diameter lubang mata (EO) mencapai $0,7 \mathrm{~cm}$ pada jantan dan $1,1 \mathrm{~cm}$ pada betina. Panjang sifon $6,0 \mathrm{~cm}$ pada jantan dan $8,0 \mathrm{~cm}$ pada betina.

Panjang lengan $(A L)$ jantan 73,3 $\mathrm{cm}$ dan $112,0 \mathrm{~cm}$ untuk betina. Pada lengan ketiga jantan di temukan Hectocotylus terdiridari ligula dengan ukuran terpanjang $0,3 \mathrm{~cm}$ dan calamus $0,1 \mathrm{~cm}$ (semua jantan memiliki ukuran calamus sama). Selaput lengan tipe $1 \mathrm{~A}$ dengan lebar selaput lengan (WD) mencapai $10,0 \mathrm{~cm}$ untuk jantan dan $13,5 \mathrm{~cm}$ untuk betina. Penghisap jumlahnya mencapai 293 buah pada lengan terpanjang (ASC) untuk jantan dan 464 untuk betina. Penghisap besar berdiameter (ASe) 1,1 cm pada jantan.

\section{Habitat}

Gurita paling banyak di temukan di pantai warre yaitu 4 individu terdiri dari 3 betina dan 1 jantan $\left(3^{0} 51^{\prime} 111^{\prime \prime} \mathrm{N}\right.$, $\left.126^{\circ} 41^{\prime} 26^{\prime \prime} \mathrm{E}\right),\left(3^{0} 51^{\prime} 10^{\prime \prime} \mathrm{N}, 126^{\circ} 41^{\prime} 26^{\prime \prime} \mathrm{E}\right)$, $\left(3^{\circ} 51^{\prime} 09^{\prime \prime} \mathrm{N}, \quad 126^{\circ} 41^{\prime} 27^{\prime \prime} \mathrm{E}\right)$ dan 
$\left(3^{0} 51^{\prime} 07^{\prime \prime} \mathrm{N}, 126^{\circ} 41^{\prime} 27^{\prime \prime} \mathrm{E}\right)$ di temukan pada ke dalaman $2 \mathrm{~m}, 3 \mathrm{~m}$ dan $3,5 \mathrm{~m}$ di dalam lubang/sarang. Gurita terbesar di temukkan di pantai Sanggelokka $\left(3^{0} 51^{\prime} 17^{\prime \prime} \mathrm{N}, \quad 126^{\circ} 40^{\prime} 31^{\prime \prime}\right)$ berjenis kelamin betina ditemukan pada ke dalaman $2 \mathrm{~m}$ di dalam lubang dan $\left(3^{0} 51^{\prime} 14 " \mathrm{~N}, \quad 126^{\circ} 40^{\prime} 32^{\prime \prime} \mathrm{E}\right)$ berjenis kelamin jantan ditemukan pada ke dalaman 3,5 $\mathrm{m}$ di dalam lubang (Gambar 12). Ada beberapa pantai tidak di temukanya gurita yaitu panta Attoaha, Awuna, Pantai Raddapa, Patunga di sebelah barat dan Wuuran, Sikkata, Nunu Umpe di sebela timur desa salibabu.
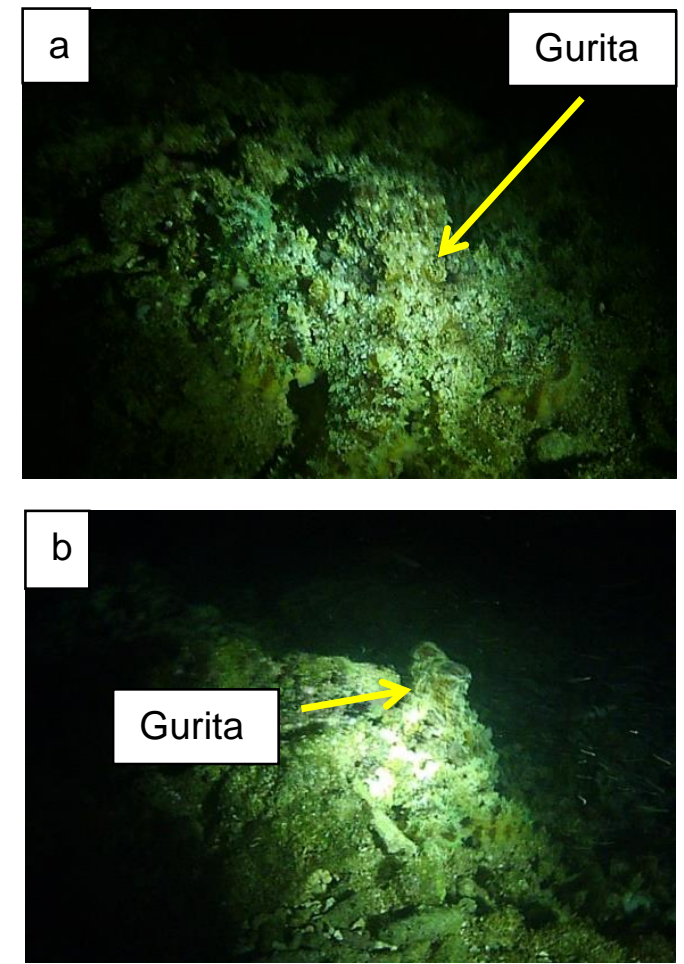

Gambar 10. Gurita ditemukan pada malam hari a. Gurita ditemukan di luar sarang pada malam hari di pantai Anneng Banua, b. Gurita ditemukan di luar sarang pada malam hari di pantai waasana.

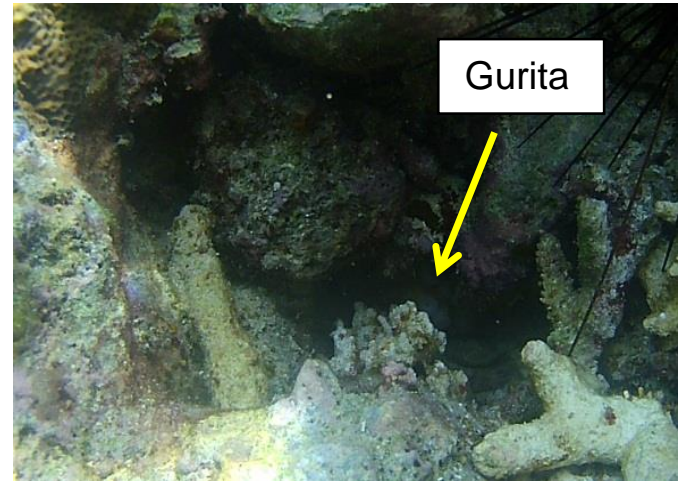

Gambar 11. Gurita di dalam lubang di pantai Lahu.

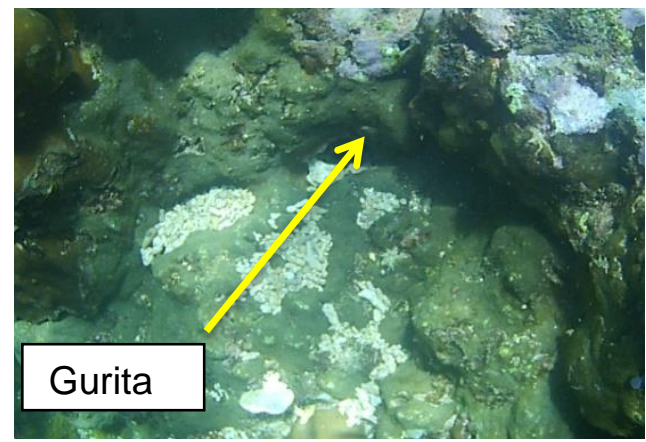

Gambar 12. Gurita ditemukan didalam lubang di pantai Warre pada siang hari

Gurita saat ditemukan pada malam hari di luar sarang/lubang memilki corak warna sama dengan lingkunganya (kamuflase) dengan posisi tubuh merangkak dan berdiri dengan menggunakan lengannya (gambar 10). Pada siang hari gurita ditemukan di dalam lubang/sarang dan memiliki corak warna putih pada lengan bercampur warna coklat muda dengan posisi tubuh lengan membungkus kepala tanpa menutupi mata. Ketika di panah (jubi) gurita akan mengeluarkan tintah dan berubah warna coklat dan coklat kehitaman dengan pola yang tidak jelas pada bagian dorsal sampai ke ujung mantel tetapi wana Ocellus, garis-garis belang dan bintik putih tampak sangat jelas. 


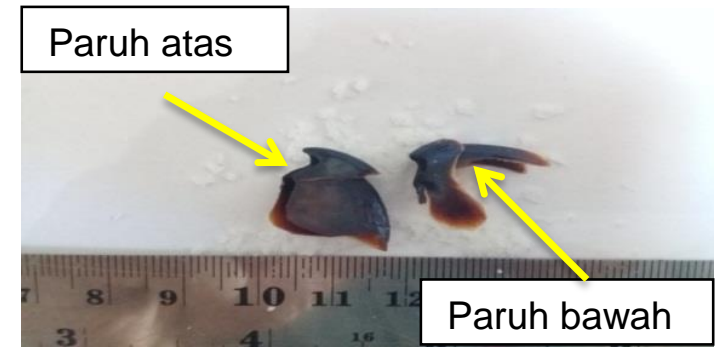

Gambar 11. Paruh Octopus cyanea

Paruh Octopus cyanea dibagi atas dua begian yaitu paru atas dan paru bawah (gambar 11). Paruh atas memiliki rostrum yang pendek, berliku, tumpul dan berwarnah hitam dengan sudut pengait agak besar. Kerudung kepala (hood) agak sempit dengan pinggiran belakang berlekuk. Puncak kepala (crest) melengkung agak panjang. Memiliki dinding lateral yang agak besar dengan tepi belakang berlekuk. Paruh bawah memiliki rostrum yang pendek dan tumpul. Kerudung kepala (hood) sempit serta puncak kepala (crest) melengkung. Dinding lateralnya kecil dan sempit serta sayap mengembang dan melebar pada bagian ujungnya.

$\begin{array}{llr}\begin{array}{l}\text { World } \\ \text { Register of }\end{array} & \begin{array}{r}\text { Marine } \\ \text { Species }\end{array} \text { (WoRMS), } \\ \text { mengklasifikasikan Octopus cyanea } \\ \text { Gray, } 1849 \text { sebagai berikut: } \\ \text { Kingdom: Animalia }\end{array}$

Phylum: Mollusca

Class: Cephalopoda

Subclss: Celeoidea

Superorder: Octopodiformes

Order: Octopoda

Suborder: Incirrata

Superfamily: Octopodoidea

Famil: Octopodidae

Genus: Octopus

\section{Species: Octopus cyanea}

Octopus cyanea memiliki ocellus yang hampir sama dengan $O$. exannulatus dan Octopus ocellate. Perbedaannya adalah ocellus $O$. exannulatus berbentuk oval datar berupa bintik hitam dan tanpa cincin. $O$. ocellate memiliki ocellus dengan cincin berwarna merah muda, biru gelap atau ungu, sedangkan ocellus $O$. cyanea berupa bintik hitam oval yang dikelilingi oleh cincin berwarna pucat dibagian dalam dan cincin berwarna gelap di bagian luar (Nateewathana 1997 dalam Paruntu, et al. 2009).

\section{KESIMPULAN DAN SARAN}

Octopus yang ditemukan di pesisir salibabu adalah Octopus cyanea Gray, 1849. Octopus betina memiliki ukuran tubuh yang lebih besar dari jantan. Jenis ini di temukan pada habitat di luar sarang malam hari dan habitat di dalam sarang pada siang hari

\section{DAFTAR PUSTAKA}

Begg, G.A., K.D. Friedland and J.B. Preace. 1999. Stock Identification and its Role in Stock Assessment and fisheries Management: an Overview. Fish Res. 43(1):1-8. doi: 10.1016/S0165-7836(99)00062-4.

Budiyanto, A., dan H. Sugiarto. 1997. Catatan Mengenai Si Tangan Delapan (Gurita/Octopus spp.) Balibang Biologi laut, Puslitbang Oseanologi LIPI, Jakarta. Oseana, Volume XXII, No 3: 25-33.

Garcia A. 2010. Comparative Study of The Morphology and Anatomy of Octopuses of The Family Octopodidae. Tesis Auckland (NZ): Auckland University of Technology. 266 hal.

Huffard, C.L and F.G. Hochberg. 2005. Description of a New Species of The Genus Amphioctopus 
(Mollusca: Octopodidae) from the Hawai'ian Islands. Malacological Society of Australasia. Molluscan Res 25(3):113-128 http://www.mapress.com/mr/

Jereb $\mathrm{P}$, Roper CFE, Norman MD, Finn J. 2016. Cephalopods of the World - An Annotated and Illustrated Catalogue of Cephalopod Species Known to Date. Volume ke-3. Roma (IT): FAO. doi: 10.1017/CBO9781107415324.004.

Norman, M.D. 1998. Octopodidae Benthic Octopus. In FAO species of Identification Guide of Fishery Purpose. The Living Marine Resources of The Westem Central Pacific. Vol 2. Cephalopods, Crustaceans, Holothurian, and Sahark, Hal. 812.

Norman, M.D. 1991. Octopus cyanea Gray, $1894 \quad$ (Mollisca: Cephalopoda) in Australian Waters: Description, Distribution and Taxonomy. Bulletin of Marine Science.

Norman, M.D and M.J. Sweeny. 1997.

The Shallow-water Octopuses (Cephalopoda: Octopodidae) of the Philippines. An International Journal of Biosystematics. CSIRO Publishing, Invertebrate Taxonomy, An International Jurnal of Biosystematics, The Shallow-water Octopuses (Ceohalopoda: Octopodida) of The Philippines Vol.1

Paruntu, C.P., F.B. Boneka dan S.L. Talare. 2009. Gurita (Cephalopoda) Dari Perairan Sangihe, Sulawesi Utara. Jurnal EKOTON Vol.9, No.2:13-27. ISSN 1412-3487.

Rompas, R.M., S. Hutabarat dan J.S. Rompas. 2007. Pengantar IImu Kelutan. Departemen Kelautan dan Perikanan, Jakarta
Roper C.F.E and G.L Voss. 1983. Guidelines for Taxonomic Descriptions of Cephalopod Species. Musem of The National Museum Victoria. Miami. No 44 (44): 49-63.

Soleh, Z. A. 2005. Ilmu statistika: Pendekatan teoritis dan aplikasi disertai contoh Penggunaan SPSS. Rekayasa sains, Bandung, $303 \mathrm{hlm}$.

Toha, A.H.A., Jeni. Widodo, N. Hakim, L. dan Sumirto, S.B. 2015. Gurita Octopus cyanea Raja Ampa. Kons. Biod Raja Ampat 4(8): 4-8. https://id.wikipedia.org/wiki/Gurit a. 2018. 